\title{
ストックを考慮した生産施設の地震時復旧曲線に関する研究 A STUDY ON SEISMIC RECOVERY CURVE OF MANUFACTURING FACTORY WITH STOCK
}

\author{
松本俊明*，中村孝明** \\ Toshiaki MATSUMOTO and Takaaki NAKAMURA
}

\begin{abstract}
Most of the manufacturing industries have a certain amount of stock, i.e., material, unfinished product, finished product and so on, in various location in the production process. By this reason, even in production stop due to an earthquake, it is possible to supply products to the market by consuming the stock. On the other hand, for the reason that it is economically disadvantageous to have a stock, there is a necessity for a rational measure in deciding the amount of stock to be kept. In this paper, to target a manufacturing industry, we proposed a simple evaluation method of the recovery curve in consideration of the stock, and discussed amount of required stock in addition to the simultaneous consumption and priority in the case of the multiple stock in a production process. Furthermore, applicability of the proposed method is examined by example of a production process.
\end{abstract}

Keywords : Recovery curve, Production process, Stock, Stand-by redundant system, System reliability 復旧曲線, 生産工程, ストック, 待機冗長システム, システム信頼性

\section{1. はじめに}

大半の製造業は、生産工程の各所に一定量の原料、中間品（仕掛 品）、製品等のストックを持つ。地震によって生産停止に至っても、 ストックを消費することにより市場に製品を供給することができる。 このため、東日本大震災以降ストックを調整する製造業が増えてい る。一方で、ストックを持つことは設備投資や流動資産の増加、こ れに伴う諸経費の増加など、経済的には見合わない行為となるため、 ストック量の調整には一定の合理性が必要となる。このような背景 から、筆者ら ${ }^{1)}$ は生産工程を模したシステム上にストックを設け、 ストック消費によって復旧曲線 2),3)が改善する効果を確率論的に評 価した。しかしながら、必要なストック量や、複数あるストックの 同時利用については課題としている。

地震時復旧曲線に関する研究を概観すると、坂本 4 は建築設備を 対象に、中村ら 2) は製造工場を対象に、Shinozuka et al. ${ }^{3}$ は電力と の連関を考慮した給水システムを対象に、それぞれ復旧曲線を評価 している。また土居ら5は水力発電の水路施設を対象に、調整池の ストック水を考慮した復旧曲線を評価している。しかしながら、調 整池の水量は無限とし、またストックは調整池 1 か所に限定してい る。静間ら ${ }^{6)}$ は高速道路を対象に、対面通行による効果を復旧曲線 で示している。特徵は、通行止め、対面通行、全面通行などの事象 に的を絞り生起確率の評価を行っている点にある。このため非常に 簡便である。製造業には様々な業種/業態があり、生産工程を模した システムは複雑化が予想される。このため、一定の制約があっても
ストック効果を含めた復旧曲線を簡便に評価できる方法が求められ ている。

そこで本論では、製造業を対象に、ストックを考慮した復旧曲線 の簡便な評価方法を提示すると共に、複数あるストックの利用優先 順位や必要なストック量について考察する。内容は、復旧曲線の定 義と評価手法一般を示し、製造業の復旧曲線に限定することで事象 の絞込みを行い、より簡便に評価できる方法を示す。この方法を基 にストックを考慮できる拡張手法を提案し、複数あるストックの同 時利用や優先順位、必要なストック量について考察する。そして、 事例による提案手法の適用性について検討する。

\section{2. 生産施設の復旧曲線の評価}

\section{1 復旧曲線の評価一般}

復旧曲線は本来の性能が低下あるいは停止し、その後元の性能に 回復するまでの経時的なプロセスを描いた曲線と定義 2),3)でき、復 旧に要する時間を横軸、本来の性能を 1.0 とした性能の復旧率を縦 軸に取る。また、確率論的アプローチを採ることから、無数の復旧 曲線が予想される中、平均的な曲線を復旧曲線として代表する。一 方、復旧曲線は時間と性能の 2 軸に描画されるため、基本的には 2 種類存在する。Fig.1の太線の復旧曲線 T と D である。D は性能を 確率変数とした縦軸に分布する曲線群の平均值を復旧時間に対し結 んだ曲線、 $\mathrm{T}$ は復旧時間を確率変数とした横軸に分布する曲線群の 平均值を性能に対し結しだ曲線である。
* (株)篠塚研究所 修士 (工学)

** (株)篠塚研究所 博士 (工学)
Shinozuka Research Institute, M.Eng.

Shinozuka Research Institute, Dr.Eng. 
復旧曲線 $\mathrm{T}$ は性能 $r$ を条件とした復旧時間 $t$ の確率密度関数 $f_{T}(t \mid r)$ より、以下のようになる。なお、性能 $r$ は連続值で表記して いるが、対象施設によっては離散值でもよい。

$$
T(r)=\int_{0}^{\infty} t \cdot f_{T}(t \mid r) d t=\int_{0}^{\infty} G_{T}(t \mid r) d t
$$

ここに、 $G_{T}(t \mid r)$ は復旧時間の超過確率関数である。復旧曲線 $\mathrm{D}$ は 復旧時間 $t$ を条件とした性能 $r$ の確率密度関数 $f_{R}(r \mid t)$ より、以下の ように求めることができる。

$$
D(t)=\int_{0}^{1} r \cdot f_{R}(r \mid t) d r=\int_{0}^{1} G_{R}(r \mid t) d r
$$

ここに、 $G_{R}(r \mid t)$ は性能の超過確率関数である。また、 $G_{R}(r \mid t)$ と $G_{T}(t \mid r)$ は以下の関係 7)にある。

$$
1-G_{R}(r \mid t)=G_{T}(t \mid r)
$$

(3)式より、 $G_{R}(r \mid t)$ あるいは $G_{T}(t \mid r)$ が求まれば、復旧曲線 $\mathrm{T} ・ \mathrm{D}$ ともに得られ、相互補完的であることが分かる。復旧曲線 D と T の 使い分けとして、機能が限定され、その機能の復旧期間を知りたい 場合に復旧曲線 $\mathrm{T}$ は有効とされ 7)、上水や電力システムのように、 システムとしての性能の低下や復旧過程を診る場合には、復旧曲線 D は実状をよく説明できるとの報告 3)がある。

一方、星谷・宮崎 ${ }^{8}$ は順次復旧、同時復旧の場合に分けそれぞれ の復旧時間の評価の基本的な考え方を示した。本論は生産工場を対 象とし、復旧は同時復旧に基づくとする。また、生産工場の場合、 復旧曲線の縦軸は、通常の生産量を 1.0 とした生産比率 2),77、総売上 げを 1.0 とした売上比率、あるいは生産量などで表す。以後、復旧 曲線の縦軸は生産量とする。

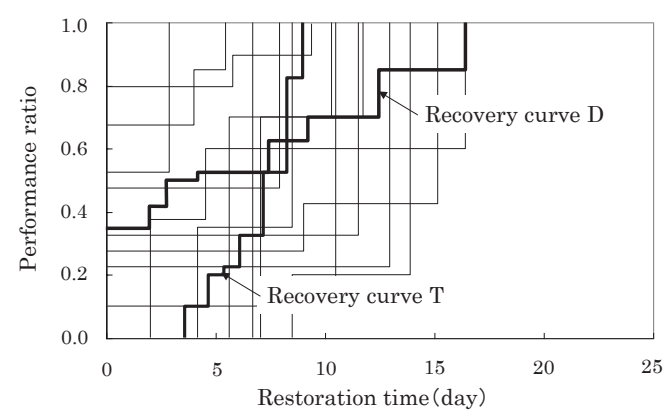

Fig.1 Explanatory sketch of recovery curves

\section{2 製造業の復旧曲線}

製造業に的を絞ると、原料の入荷から製品出荷までの工程は多様 かつ複雑であるが、任意の製品を取上げその工程を追うと、直列シ ステムにモデル化できる。一例を Fig. 2 に示す。図は $m$ 種の製品を 生産する工程をシステムとしてモデル化したもので、 $\square て ゙$ 示す $\mathrm{A}_{j}$, $\dot{j} 1 \sim n$ は各種製造装置やユーティリティなどのいわゆる構成要素 である。また $r_{i}, \dot{I}=1 \sim m$ は各製品種の単位時間当たりの生産量で、 $m$ 個の離散值をとる。図より、生産量 $r_{1}$ である製品 1 の生産工程は $\mathrm{A}_{1}-\mathrm{A}_{2}-\mathrm{A}_{3}-\mathrm{A}_{4}$ の直列システムに、同様に、 $r_{2}$ は $\mathrm{A}_{1}-\mathrm{A}_{2}-\mathrm{A}_{3}-\mathrm{A}_{5}$ の直列システムにそれぞれ分解できる。つまり生産工程は $m$ 個の直
列システムに分解でき、これにより直列システムが健全か否かの 2 值問題に帰着できる。

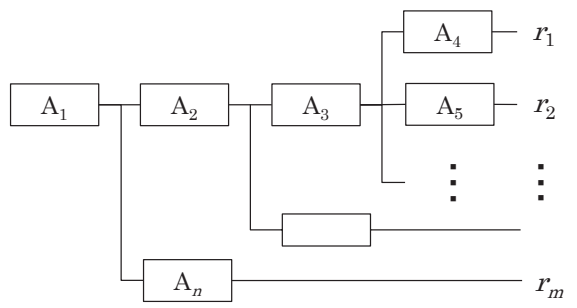

Fig.2 An example of system model of a production process

工場関係者の多くは、どの生産ライン、あるいはどの製品がいつ 復旧するのかなど、生産ラインの再稼働時期や各製品の出荷再開時 間を把握したいと考えている。そこで、製品 $i$ が出荷できるまでの 時間の期待值は以下のように求めることができる。

$$
T\left(r_{i}\right)=\int_{0}^{\infty} G_{T}\left(t \mid r_{i}\right) d t \quad, i=1 \sim m
$$

復旧曲線を求めるには、製品 $i$ の復旧時間の期待値を短い順（復旧 順）に列記する。そして、(5)式に示寸 $r_{i}$ の累積值を縦軸に、対応す る復旧時間を横軸にとれば復旧曲線 $\mathrm{T}$ が得られる。

$$
r_{k}=\sum_{i=1}^{k} r_{i}
$$

ここに、 $r_{k}$ は製品 1 製品 $k$ までの生産量の累積值である。

一方、(2)式に(3)式を適用し、さらに生産量 $r_{i}$ を考慮すると、(2) 式は以下のようになる。

$$
D(t)=1-\sum_{i=1}^{m} r_{i} \cdot G_{T}\left(t \mid r_{i}\right)
$$

ここに、 $G_{T}\left(t \mid r_{i}\right)$ は生産量 $r_{i}$ である製品 $i$ の復旧時間 $t$ の超過確率 関数を表す。また、以下のように表すこともできる。

$$
D(t)=\sum_{i=1}^{m} r_{i} \cdot F_{T}\left(t \mid r_{i}\right)
$$

ここに、 $F_{T}\left(t \mid r_{i}\right)$ は生産量 $r_{i}$ である製品 $i$ の復旧時間 $t$ の非超過確 率関数である。(7)式は各生産ラインの健全確率に、それぞれの生産 量を乗じ総和することで、復旧曲線 $\mathrm{D}$ が求められることを示してい る。これより、 $F_{T}\left(t \mid r_{i}\right)$ 、あるいは $G_{T}\left(t \mid r_{i}\right)$ が求められれば、復旧 曲線 T、D が共に得られる。

\section{3 構成要素の健全確率と非超過確率関数 $\mathrm{F}_{\mathrm{Aj}}(\mathrm{t})$ の評価}

任意の構成要素 $\mathrm{A}_{j}, j=1 \sim n$ （各種製造装置やユーティリティ）に おける地震時の損傷確率は、軽微、中破、大破等の被害レベルを設 定し、それぞれの Fragility Curve から得る。また、復旧時間は軽 微であれば $t_{\text {minor }}$ 、大破であれば $t_{\text {major }}$ など、被害レベルに応じて設 定する。この場合、Fig. 3 の右に示すように、復旧時間を確率変数 とした非超過確率を求めることができる。図の左は Fragility Curve であり、地震動 $500 \mathrm{Gal}$ が作用した際の被害レベルの確率を読むこ とができ、対応する確率から右の非超過確率を求める。図より健全 確率（軽微以下）は 0.5 と読め、発災から $t_{\text {minor }}$ 時間経過すると軽微 被害は修復されることから、健全確率（中破以下）は 0.8 に改善す 
る。最大の停止時間 $\left(t_{\max }\right)$ 経過すれば完全復旧し、健全確率は 1 になる。つまり、構成要素の健全確率は、発災からの経過時間に依 存し、その值は被害レベル毎の Fragility Curve に対応した復旧時 間の非超過確率関数 $F_{A}(t)$ によて完全に記述できる。各構成要素 の復旧は、同時かつ独立に行われると仮定する。これは、装置 $\mathrm{A} の$ 据え付け後に装置 B を設置、などといった若干の時間差はあるもの の、生産再開を早期化するため、大局的には、機器の発注、搬入、 調整等はほぼ同時期に行うとの仮定による。
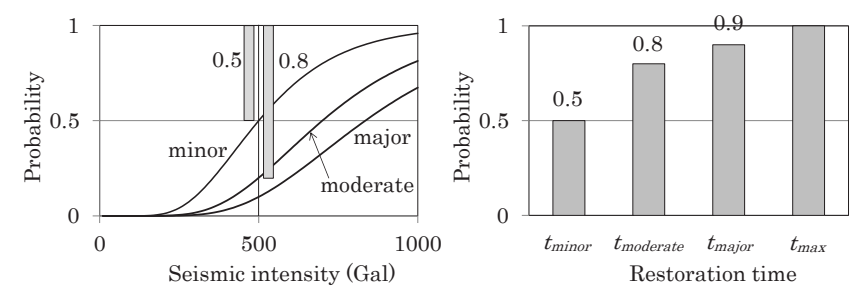

Fig.3 Fragility curves and non-excess probability function of component

生産量 $r_{1}$ の製品が生産できる確率は、直列システム $\mathrm{A}_{1}-\mathrm{A}_{2}-\mathrm{A}_{3}$ 一 $\mathrm{A}_{4}$ の健全確率を求めればよく、以下のように表すことができる。

$$
F_{T}\left(t \mid r_{1}\right)=F_{A 1}(t) F_{A 2}(t) F_{A 3}(t) F_{A 4}(t)
$$

(8)式より、復旧時間 $t$ に対応した直列システムの健全確率が得られ る。 $r 2 \sim r_{m}$ も同様に計算すれば、(7)式から復旧曲線 D が得られ、(4) 式と(5)式より、復旧曲線 $\mathrm{T}$ を得る。

\section{3. ストックを考慮した復旧曲線の評価}

\section{1 待機冗長システムによるストック効果}

Fig. 2 に示したシステムモデルから直列システムに分解した $\mathrm{A}_{1} \sim$ $\mathrm{A}_{4}$ を取上げる。そして Fig.4(a)に示すように、システム上に仕掛品

（以下ストック）が存在するケースを想起する。ストックは $\mathrm{Z}_{1} 、 \mathrm{Z}_{2}$ の 2 カ所である。ストックは無尽蔵にあると仮定し、ストックはス トックの上流側システムが不健全な場合にのみ消費されると考える と、Fig.4(b)のように待機圥長システム (stand-by redundant system）としてモデル化できる。なお、待機圥長システムは、常時 は使用せず待機させておき、地震等で被災した際に稼働させるシス テムを言う。本論では待機させておく構成要素がストックに当たる。

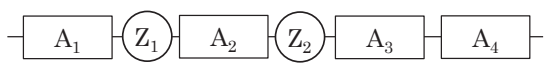

(a) Series system with stock

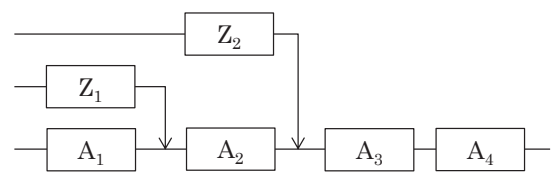

(b) System model arranged by stand-by redundancy

Fig.4 A series system disjointed from the production process

先ず、Fig.4の $\mathrm{Z}_{1}$ にストックがある場合「 $\mathrm{Z}_{1}$ のみ」、ストックは
要素 $\mathrm{A}_{1}$ が不健全な場合にのみ消費されることから、システムの健全 事象は以下のように表すことができる。

$$
\begin{gathered}
\left(A_{1}+\overline{A_{1}}\right) \cdot A_{2} \cdot A_{3} \cdot A_{4} \\
=A_{2} \cdot A_{3} \cdot A_{4}
\end{gathered}
$$

ここに、+は和事象、・は積事象、一は余事象である。以下、 $A_{1}$ 、 $\mathrm{A}_{2}$ ・ ・ は要素の健全事象とする。(9)式より、システムの健全確率 は以下のようになる。

$$
F_{T}\left(t \mid r_{1}\right)=F_{A 2}(t) F_{A 3}(t) F_{A 4}(t)
$$

$\mathrm{Z}_{2}$ にストックがある場合「 $\mathrm{Z}_{2}$ のみ」、 $\mathrm{Z}_{1}$ と $\mathrm{Z}_{2}$ 双方にストックがある 場合「 $\left.Z_{1}+Z_{2}\right\rfloor も$ 同様に計算できる。ストックがない場合も含めた システムの健全事象と健全確率を Table1 にまとめて示す。なお、 表中の事象演算の詳細は付録を参照されたい。

次に、ストック消費に着目する。「 $\mathrm{Z}_{1}$ のみ」の場合、ストックが 消費される事象は、待機冗長システムの性質から以下のように表す ことができる。

$\overline{A_{1}} \cdot A_{2} \cdot A_{3} \cdot A_{4}$

また、(11)式より、ストックが消費される確率は以下のようになる。

$$
F_{Z 1}\left(t \mid r_{1}\right)=\left(1-F_{A 1}(t)\right) F_{A 2}(t) F_{A 3}(t) F_{A 4}(t)
$$

$\left\lceil\mathrm{Z}_{2}\right.$ のみ」「 $\mathrm{Z}_{1}+\mathrm{Z}_{2} 」$ も同様に計算でき、これらを Table2 にまと めて示す。

Table1 Logical operations and soundness probabilities

\begin{tabular}{|c|c|c|}
\hline & Soundness event & Soundness probability \\
\hline Without stock & $A_{1} \cdot A_{2} \cdot A_{3} \cdot A_{4}$ & $F_{A 1}(t) F_{A 2}(t) F_{A 3}(t) F_{A 4}(t)$ \\
\hline Only $\mathrm{Z}_{1}$ & $A_{2} \cdot A_{3} \cdot A_{4}$ & $F_{A 2}(t) F_{A 3}(t) F_{A 4}(t)$ \\
\hline${\text { Only } \mathrm{Z}_{2}}$ & $A_{3} \cdot A_{4}$ & $F_{A 3}(t) F_{A 4}(t)$ \\
\hline $\mathrm{Z}_{1}+\mathrm{Z}_{2}$ & $A_{3} \cdot A_{4}$ & $F_{A 3}(t) F_{A 4}(t)$ \\
\hline
\end{tabular}

Table2 Logical operations and stock consumption probabilities

\begin{tabular}{|c|c|c|}
\hline & $\begin{array}{c}\text { Stock consumption } \\
\text { event }\end{array}$ & Stock consumption probability \\
\hline Only Z $_{1}$ & $\overline{A_{1}} \cdot A_{2} \cdot A_{3} \cdot A_{4}$ & $\left(1-F_{A 1}(t)\right) F_{A 2}(t) F_{A 3}(t) F_{A 4}(t)$ \\
\hline Only Z $_{2}$ & $\overline{A_{1} \cdot A_{2}} \cdot A_{3} \cdot A_{4}$ & $\left(1-F_{A 1}(t) F_{A 2}(t)\right) F_{A 3}(t) F_{A 4}(t)$ \\
\hline $\mathrm{Z}_{1}+\mathrm{Z}_{2}$ & $\overline{A_{1} \cdot A_{2}} \cdot A_{3} \cdot A_{4}$ & $\left(1-F_{A 1}(t) F_{A 2}(t)\right) F_{A 3}(t) F_{A 4}(t)$ \\
\hline
\end{tabular}

Table2 のストック消費確率に、単位時間当たりの生産量 $r_{1}$ を乗じ れば、単位時間当たりのストック消費量の期待值が求められる。こ のように、待機圥長システムを含めた事象演算を用いることで、シ ステムの健全事象等を簡便に記述することができる。同時に、事象 の確率演算も簡単になり、2.2 節で示した復旧曲線の評価を簡便に 行うことができる。

$\mathrm{Z}_{2}$ のみにストックがあるケースを取り上げ、ストックなしのシス テムの健全確率にストック消費の確率を加えると以下のようになる。

$$
\begin{aligned}
& F_{A 1}(t) F_{A 2}(t) F_{A 3}(t) F_{A 4}(t) \\
& \quad+\left(1-F_{A 1}(t) F_{A 2}(t)\right) F_{A 3}(t) F_{A 4}(t) \\
& \quad=F_{A 3}(t) F_{A 4}(t)
\end{aligned}
$$


(13)式は、Table1 の「 $\mathrm{Z}_{2}$ のみ」の健全確率と一致する。これはスト ックの効果は、ストックがない場合の生産量にストックの消費量を 加えることで求められることを示し、またストックの消費量は、ス トックなしの生産量とストックがある場合の生産量の期待值から、 求められることを示している。

次に、Table1 と Table2 より、「 $\mathrm{Z}_{2}$ のみ」と「 $\mathrm{Z}_{1}+\mathrm{Z}_{2} 」$ は同じ結果 である。これより、ストック効果は最下流に位置するストックによ って決定し、上流に位置するストックに依存しないことが分かる。

\section{2 複数あるストックの利用優先順位と必要ストック量}

ストック効果は最下流に位置するストックによって決定すること から、システム上に 2 か所以上ストックがあり、且つストックが無 尽蔵にある場合、上流側に位置するストックを使用寸る機会はない。 ところが現実には、ストックを置くスペースやコスト面から考えて、 下流側に集中してストックを置くことは難しく、また、ストック量 の有限性や上流側ストックの有効活用などから、ストックの位置に 関わらずストックをバランスよく（消費を特定のストックに集中さ せない）有効に利用することが要求される。ここで、Table2 の「Z のみ」と「 $\left.\mathrm{Z}_{1}+\mathrm{Z}_{2}\right\rfloor$ のトック消費の事象より、以下の関係が恒に 成立することが分かる。

$$
\overline{A_{1} \cdot A_{2}} \cdot A_{3} \cdot A_{4} \supset \overline{A_{1}} \cdot A_{2} \cdot A_{3} \cdot A_{4}
$$

つまり、「 $\mathrm{Z}_{1}$ のみ」の消費は「 $\left.\mathrm{Z}_{1}+\mathrm{Z}_{2}\right\rfloor$ のトック消費の部分集合 である。必然的に以下も成立する。

$$
\begin{aligned}
\left(1-F_{A 1}(t) F_{A 2}(t)\right) F_{A 3}(t) F_{A 4}(t) & \\
& >\left(1-F_{A 1}(t)\right) F_{A 2}(t) F_{A 3}(t) F_{A 4}(t)
\end{aligned}
$$

(15)式は、上流側に位置するストックの消費確率は下流側に位置す るストックのそれに含まれることを表している。

そこで、ライン上に複数のストックがある場合、上流側に位置す るストックから優先的に消費する、といったルールを設定する。こ れにより、上流側ストックを有効活用でき、また相対的に消費の多 い下流側ストックの消費を抑制できる。具体的には、「 $\mathrm{Z}_{1}$ のみ」の ストックの単位時間当たりの消費量の期待值は、

$$
Z_{1}(t)=\left(1-F_{A 1}(t)\right) F_{A 2}(t) F_{A 3}(t) F_{A 4}(t) \cdot r_{1}
$$

となる。 $\mathrm{Z}_{2}$ のそれは、「 $\mathrm{Z}_{1}+\mathrm{Z}_{2} 」$ の消費から「 $\mathrm{Z}_{1}$ のみ」の消費を差 引けばよく、以下のようになる。

$$
\begin{aligned}
Z_{2}(t)= & \left(1-F_{A 1}(t) F_{A 2}(t)\right) F_{A 3}(t) F_{A 4}(t) \cdot r_{1}-Z_{1}(t) \\
& =\left(1-F_{A 2}(t)\right) F_{A 3}(t) F_{A 4}(t) \cdot r_{1}
\end{aligned}
$$

つまり、上流側ストックの消費事象は、下流側ストックの消費事象 の部分集合であることから、下流側ストックの単位時間あたりの消 費量は、上流側ストックのそれを差引くことで求められる。一方、 必要なストック量は、復旧曲線の改善効果が最大となる量であり、 ストック $\mathrm{Z}_{1}$ の消費量は以下となる。

$$
Z_{1 R E Q}=\int_{0}^{t_{\max }} Z_{1}(t) d t
$$

ストック $\mathrm{Z}_{2}$ の消費量は、(17)式を(18)式と同様に積分することで得 られる。
なお、「 $\mathrm{Z}_{2}$ の」の消費量は、Table2 に示した「 $\mathrm{Z}_{2}$ のみ」のスト ック消費確率に、単位時間当たりの生産量 (ここでは $r_{1}$ )を乗じて、 (18)式に適用すればよい。

\section{4. 事例評価の対象}

生産工程を模したシステムモデルを Fig.5(a)に示す。図は化学製 品を製造する工場で、ロはユニットを表し、ユニット内に各種製造 装置やユーティリティなどがある。ユニット間には一定量の仕掛品 （○印で示した $Z_{\mathrm{A}} 、 \mathrm{Z}_{\mathrm{C}} 、 \mathrm{Z}_{\mathrm{F}}$ ) があり、通常時は各ユニットによって 異なる生産量の調整役を担っている。製品は 6 種で、図中の $\Rightarrow$ から 出荷される。Fig.5(a)は待機圥長システムの形で表すと Fig.5(b)のよ うに整理できる。直列システムへの分解は製品種と同じ 6 で、分解

\begin{tabular}{|c|c|c|c|c|}
\hline Unit & $\begin{array}{c}\text { Amount of products } \\
\text { (per day) }\end{array}$ & $\begin{array}{c}\text { Damage } \\
\text { level }\end{array}$ & $\begin{array}{l}\text { Earthquake resistance } \\
\text { (median of strength) (Gal) }\end{array}$ & $\begin{array}{l}\text { Restoration } \\
\text { time (day) }\end{array}$ \\
\hline \multirow{3}{*}{ A } & \multirow{3}{*}{100} & Minor & 500 & 5 \\
\hline & & Moderate & 600 & 15 \\
\hline & & Major & 700 & 40 \\
\hline \multirow{3}{*}{ B } & \multirow{3}{*}{10} & Minor & 320 & 1 \\
\hline & & Moderate & 400 & 15 \\
\hline & & Major & 600 & 30 \\
\hline \multirow{3}{*}{$\mathrm{C}$} & \multirow{3}{*}{70} & Minor & 350 & 5 \\
\hline & & Moderate & 500 & 15 \\
\hline & & Major & 640 & 30 \\
\hline \multirow{3}{*}{ D } & \multirow{3}{*}{20} & Minor & 350 & 1 \\
\hline & & Moderate & 450 & 10 \\
\hline & & Major & 580 & 30 \\
\hline \multirow{3}{*}{$\mathrm{E}$} & \multirow{3}{*}{30} & Minor & 470 & 5 \\
\hline & & Moderate & 600 & 20 \\
\hline & & Major & 800 & 35 \\
\hline \multirow{3}{*}{$\mathrm{F}$} & \multirow{3}{*}{40} & Minor & 370 & 1 \\
\hline & & Moderate & 450 & 20 \\
\hline & & Major & 550 & 40 \\
\hline \multirow{3}{*}{ G } & \multirow{3}{*}{20} & Minor & 450 & 5 \\
\hline & & Moderate & 550 & 20 \\
\hline & & Major & 700 & 30 \\
\hline \multirow{3}{*}{$\mathrm{H}$} & \multirow{3}{*}{10} & Minor & 480 & 5 \\
\hline & & Moderate & 600 & 10 \\
\hline & & Major & 750 & 35 \\
\hline \multirow{3}{*}{ I } & \multirow{3}{*}{10} & Minor & 370 & 1 \\
\hline & & Moderate & 460 & 15 \\
\hline & & Major & 650 & 30 \\
\hline
\end{tabular}

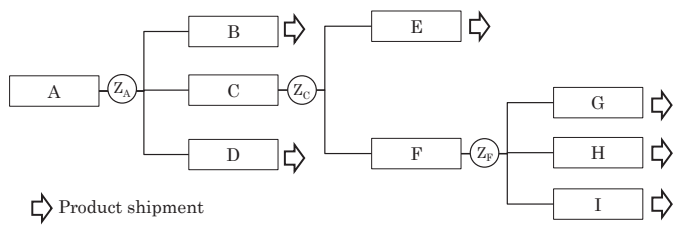

(a) System model of production process

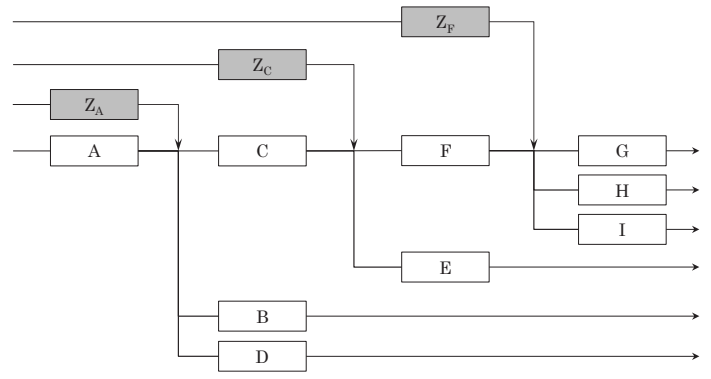

(b) System model arranged by stand-by redundancy Fig.5 The system model of the production process as an example

Table3 Specification of the Units 
された生産ラインから造られる製品名を B、D、E、G、H、I と記 す。Table3 には各ユニットの耐震性能等の諸元を示す。被害レベル は小破、中破、大破を設けそれぞれのレベルに対応する耐力中央值 （地表面最大加速度換算值：Gal）と復旧日数を設定した。また、 日当たりの生産量は表の通りとする。製品 $\mathrm{B} 、 \mathrm{D} 、 \mathrm{E} 、 \mathrm{G} 、 \mathrm{H} 、 \mathrm{I}$ そ れぞれの生産量を和算すると 100 である。作用する地震動強さは一 律 $400 \mathrm{Gal}$ （地表面）とし、耐力と作用地震動のばらつきを考慮し た複合偏差を 0.5 とした。これら情報から対数正規分布の累積分布 関数として Fragility curve を評価し、各ユニットの被害レベルの発 生確率と非超過確率関数を求めた。なお、各ユニット間の損傷は独 立としストックの被害は考えない。

\section{5. 解析結果}

\section{1 ストック消費量の考察}

各ストックの消費は、発苂からの経過時間に依存するが、ここで は発災後経過日数が 15 日から 20 日の間におけるストック消費に着 目する。Fig.6 は、 $\mathrm{Z}_{\mathrm{A}} 、 \mathrm{Z}_{\mathrm{C} 、} \mathrm{Z}_{\mathrm{F}}$ の各ストックが個別に存在する場合 の日当たりのストック消費量を比較したもので、各製品のストック 消費量を図示している。ストック $\mathrm{Z}_{\mathrm{F}}$ は製品 $\mathrm{G} 、 \mathrm{H} 、 \mathrm{I}$ の 3 種に関係 しトータルの消費量は最大である。一方の上流に位置する $\mathrm{Z}_{\mathrm{A}}$ はトー タルの消費量は少ないものの、全ての製品に対して消費している。 各ストックが個別に存在する場合、下流に位置するストックの消費 は相対的に大きくなる。これは損傷要因となる上流側ユニットの影 響を実質排除できる待機冗長システムの特徵的傾向である。

一方、3.2 節で述べた通り、現実には、ストックを置くスペース やコスト面から考えて、下流側に集中してストックを置くことは難 しく、また、ストック量の有限性や上流側ストックの有効活用など から、ストックの位置に関わらずストックをバランスよく（消費を 特定のストックに集中させない)有効に利用することが求められる。 このような観点から、上流側ストックを有効活用し相対的に消費の 多い下流側ストックの消費を抑制する必要がある。そこで、 $\mathrm{Z}_{\mathrm{A} 、} 、 \mathrm{Z}_{\mathrm{C}} 、$ $Z_{\mathrm{F}}$ を同時利用し、上流側に位置するストックから優先的に消費する、 といったルールに基づき、ストック消費量を比較したのが Fig.7 で ある。

先ず、最上流に位置する $\mathrm{Z}_{\mathrm{A}}$ の消費を優先するため、 $\mathrm{Z}_{\mathrm{A}}$ の消費量 は個別に存在するケースと同じ量となる。 Z Z については、 Z に存在するケース (Fig.6) の消費量から、 $\mathrm{Z}_{\mathrm{A}}$ で消費される製品 (E、

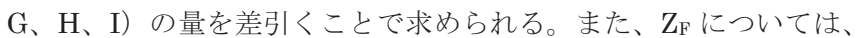
$\mathrm{Z}_{\mathrm{F}}$ が個別に存在するケース（Fig.6）の消費量から、 Z $\mathrm{Z}$ が個別に存 在するケース（Fig.6）で消費される製品（G、H、I）の量を差引く ことで求められる。ストックを同時利用した本例では、 $\mathrm{Z}_{\mathrm{C}}$ の消費量 が最も少ない結果になった。

このようにして得られた日当りのストック消費量を復旧時間に渡 って積分すれば必要なストック量を得る。この点は後述する。

\section{2 復旧曲線の評価}

ストックがある場合とない場合の復旧曲線 $\mathrm{T}$ を評価したものを

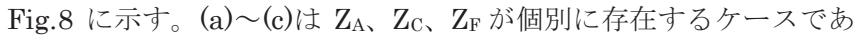
り、比較のためストックを考慮しない復旧曲線も示している。(d) は $\mathrm{Z}_{\mathrm{A}} 、 \mathrm{Z}_{\mathrm{C} 、} \mathrm{Z}_{\mathrm{F}}$ を同時利用した際の復旧曲線である。

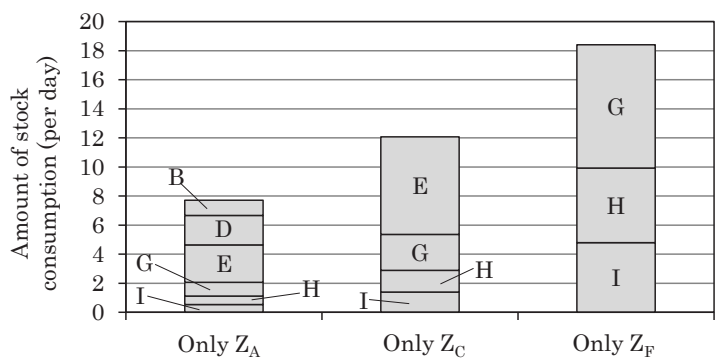

Fig.6 Amount of Individual stock consumption (Elapsed time after an earthquake 15-20 day)

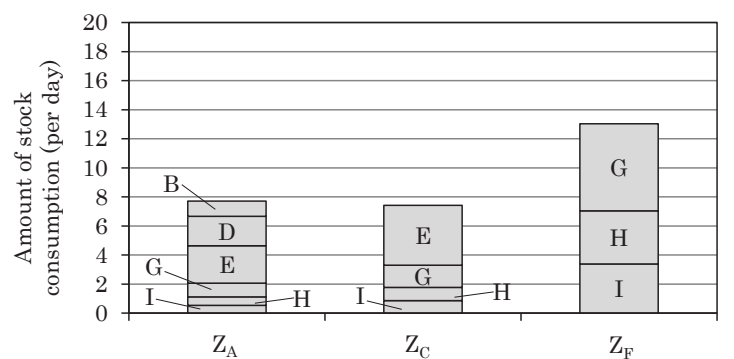

Fig.7 Amount of simultaneous stock consumption (Elapsed time after an earthquake 15-20 day)

先ず、復旧曲線 $\mathrm{T}$ は、施設の復旧工事が完了する日数を示すので はなく、各製品の出荷が可能になるまでの日数を示している。

Fig.8 の各図に示したストックなしの復旧曲線によると、製品出 荷が可能となるのは、製品 D、B、E、H、G、I の順となっている。 これは、各製品の生産工程において、例えば、ユニット D の上流側 に位置する構成要素はユニット $\mathrm{A}$ のみであるのに対し、ユニット $\mathrm{H}$ のそれは A、C、Fの３ユニットと多くなるためである。なお、Table3 に示寸通り、本事例モデルでは極端に耐震性能が劣るユニットは無 い。しかしながら、ユニット D の耐震性能が極端に劣るといった場 合、上流側ユニットの数によらず、製品 $\mathrm{D}$ の出荷再開時間の期待値 が、相対的に最も遅延する可能性があることに注意を要する。

一方、(a)に示した $\mathrm{Z}_{\mathrm{A}}$ の個別消費による復旧曲線によると、いず れの製品においても、出荷までの日数は改善されていることが分か る。これは、Fig.6 に示寸通り、 $\mathrm{Z}_{\mathrm{A}}$ の消費は、全ての製品に関わっ ているためである。

(b)に示した $\mathrm{Z}_{\mathrm{C}}$ の個別消費による復旧曲線によれば、 $\mathrm{Z}_{\mathrm{C}}$ の消費に よって、製品 $\mathrm{E} 、 \mathrm{G} 、 \mathrm{H} 、 \mathrm{I}$ の出荷が再開する日数が改善している。 これは、Fig.6より、ストック $\mathrm{Z}_{\mathrm{C}}$ の消費は、製品 $\mathrm{E} 、 \mathrm{G} 、 \mathrm{H} 、 \mathrm{I}$ に関 わり、Zcより上流に位置する製品 $\mathrm{B} 、 \mathrm{D}$ の製造に寄与しないためで ある。

(c)に示したストック $\mathrm{Z}_{\mathrm{F}}$ の個別消費による復旧曲線より、 $\mathrm{Z}_{\mathrm{F}}$ の消 費によって、製品 G、H、I の出荷再開までの日数が大きく改善し ている。これも同様に、Fig.6より、 $\mathrm{Z}_{\mathrm{F}}$ の消費は下流に位置する製 品 $\mathrm{G} 、 \mathrm{H} 、 \mathrm{I}$ の製造のみに関わっているためである。また、Fig.6に 示寸通り、下流側に位置するストック $\mathrm{Z}_{\mathrm{F}}$ の消費量はより顕著である。 これは、 $\mathrm{Z}_{\mathrm{F}}$ より下流側に位置する構成要素の数が、 $\mathrm{Z}_{\mathrm{A}}$ や $\mathrm{Z}_{\mathrm{C}}$ のそれ らに比べ、少なくなるためである。この影響は、(c)に示したストッ ク $\mathrm{Z}_{\mathrm{F}}$ を個別消費した場合の復旧曲線 $\mathrm{T}$ にも表れている。 
(d)に示した $Z_{A} 、 Z_{C} 、 Z_{F}$ の同時利用による改善効果が著しい。ま た、各製品の復旧順位を見ると、(d)は(a)〜 (c) と比較して直線的に 立ち上り、ほぼ同時に製品出荷が可能となることが分かる。これは、 システムの各所に配置されているストック全てを同時に消費したこ とにより、6 種の製品出荷に対しストックが遍く有効に利用されて いることを意味している。

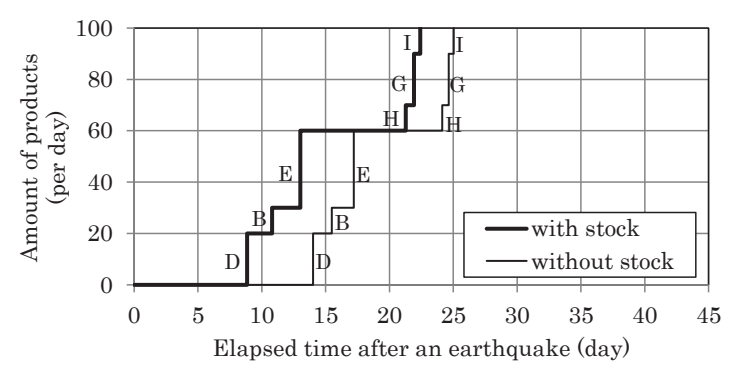

(a) Stock $Z_{\mathrm{A}}$ consumption

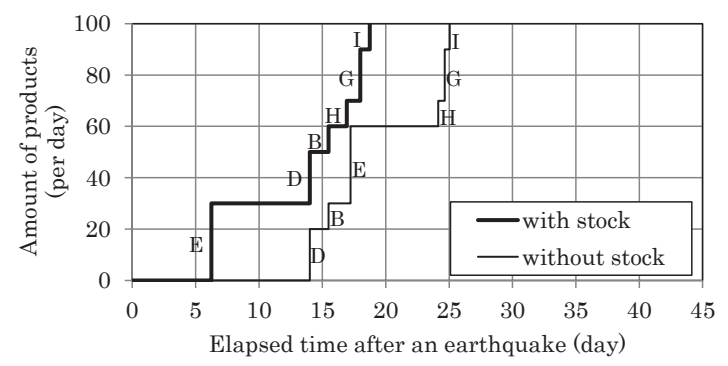

(b) Stock $Z_{C}$ consumption

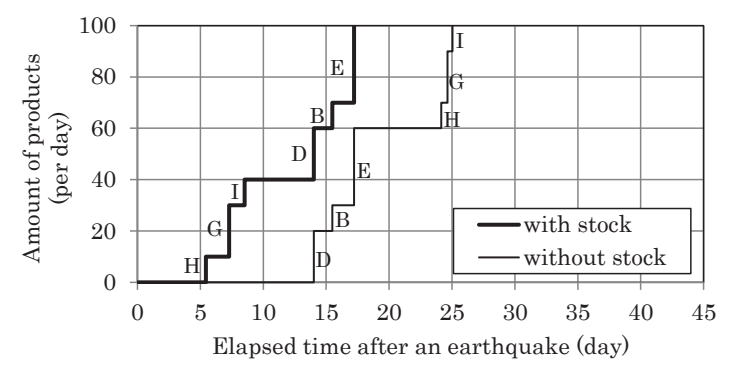

(c) Stock $Z_{F}$ consumption

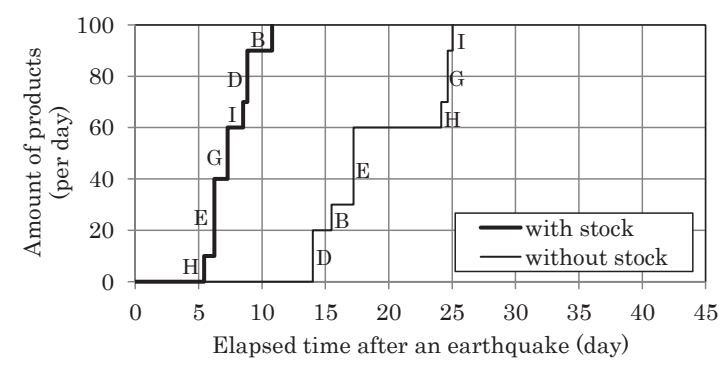

(d) Simultaneous stock consumption

Fig.8 Comparison of recovery curves $(\mathrm{T})$ with and without stock consumption

次に、 $\mathrm{Z}_{\mathrm{A}} 、 \mathrm{Z}_{\mathrm{C} 、} 、 \mathrm{Z}_{\mathrm{F}}$ を同時利用した際の復旧曲線 $\mathrm{D}$ を Fig.9 に示す。 比較のためストックを考慮しない復旧曲線も併記している。復旧曲 線 $\mathrm{T}$ と同様に、ストックによる改善効果は著しい。復旧曲線 D は、 平均值ではあるものの、発災による製品出荷の低下量とその回復過
程を知ることができる。例えば、発災当初、製品出荷量は日当り 15 まで低下するものの、ストックを消費することで 53 に改善するこ とが分かる。しかしながら、前述したように工場関係者はどの製品 がいつ出荷できるのか、いわゆる製品毎の出荷再開時間を把握した いと考えている。復旧曲線 D からは、このような情報を読み取るこ とはできない。また、各生産ラインは生産できるか否かの 2 值と仮 定していることから、工場全体としては B、D、E、G、H、I の 6 種の製品の生産量の組み合わせ以外の生産量は、現実にはあり得な いことになる。つまり、製品出荷量が日当り 15 、あるいは $53 、 と$ いった数量は、計算上の期待值としてはあり得るものの、工場関係 者にとっては実感を伴わない。製品種が限定された生産施設では、 復旧曲線 T の方がより有益と考える。一方で、製品種が多く、生産 工程が細分化され、かつ発災時に最低限必要となる生産量を把握し たいといった要請に対しては、復旧曲線 D が有効と考える。

両曲線の使い分けは、2.1 節で述べたように対象施設によって異 なるが、本例のように、6 種の製品であれば、復旧曲線 Tによって 確認できる情報で十分と考える。しかしながら、製品種が多数であ ったり、発災による出荷量の低下を把握したい場合には、復旧曲線 Tと D を併用することが、良いと考える。なお、ここで示したスト ック消費は、評価対象施設の耐震性能や生産工程、ストックの位置 等に依存するもので一般的な傾向を示すものではない。

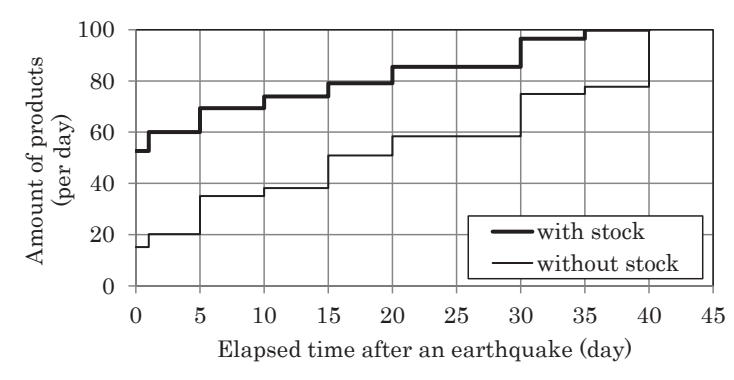

Fig.9 Comparison of recovery curves (D) with and without simultaneous stock consumption

\section{3 必要ストック量の検討}

復旧曲線の改善効果を最大にするストック量を評価する。これは (18)式に従い、日当りのストック消費量を復旧時間に渡って積分す ることで得られる。先ず、ストック $\mathrm{Z}_{\mathrm{A}} 、 \mathrm{Z}_{\mathrm{C} 、} \mathrm{Z}_{\mathrm{F}}$ が個別に存在する 場合、ストック $\mathrm{Z}_{\mathrm{A}}$ の総消費量は $386 、 \mathrm{Z}_{\mathrm{C}}$ は $598 、 \mathrm{Z}_{\mathrm{F}}$ は 700 となる。 これらの值は個別消費したときの復旧曲線の改善効果を最大化する 必要量である。一方、 $\mathrm{Z}_{\mathrm{A} 、} 、 \mathrm{Z}_{\mathrm{C} 、} 、 \mathrm{Z}_{\mathrm{F}}$ を同時利用した場合、 $\mathrm{Z}_{\mathrm{A}}$ の総消 費量は同じであるが、ストック Z $\mathrm{C}$ は $362 、 Z_{\mathrm{F}}$ は 431 となる。これ らの值は同時利用した際の復旧曲線の改善効果を最大化するもので、 各ストックの必要量となる。また、同時利用した際のそれぞれのス トック消費量を、ユニット A、C、F の日当たり生産量 100、70、 40 で除すと、 $\mathrm{Z}_{\mathrm{A}}$ はおよそ 4 日分 $(386 \div 100)$ 、同様に、 $\mathrm{Z}_{\mathrm{C}}$ はおよ そ 5 日分、 $Z_{F}$ はおよそ 11 日分のストックに相当する。

以上のようにして得られた必要なストック量を、工場関係者は通 常の生産活動の中で、ローリングしながら維持すればよいことにな る。一方、本論では復旧曲線の改善効果が最大となるストック量を 必要量としたが、工場関係者自らが、発災時に目標とする生産量や 
復旧日数を設定する場合がある。また、生産施設の耐震化も併せて 復旧曲線の改善を目指寸場合もある。このような場合にも、本論で 提案した必要なストック量の評価方法は適用できる。

\section{6. まとめ}

製造工程を直列システムに分解することで、より簡便に復旧曲線 を評価する方法を示し、これをべースにストックを考慮できる拡張 手法を提案した。本論の範囲で得られた知見をまとめると以下のよ うになる。

・ストックは待機冗長システムとしてモデル化できる。

・直列システム上では、ストックが無尽蔵にある場合、ストック効 果は最下流に位置するストックによって決定し、上流に位置するス トックに依存しない。

・復旧曲線の評価において、ストック効果はストックがない場合の 生産量にストックの消費量を加えることで求められる。またストッ クの消費量はストックなしの生産量とストックがある場合の生産量 の差として求められる。

・直列システム上に複数のストックがある場合、上流側ストックの 消費事象は下流側ストックの消費事象の部分集合となる。

・上流側ストックを優先的に利用することで、バランスのよい（消 費を特定のストックに集中させない）ストック消費が実現できる。

・どの製品がいつ出荷できるのかを把握したい場合には復旧曲線 $\mathrm{T}$ が有効である。

・発災時に最低限必要となる生産量を把握したい場合には、復旧曲 線 T に加え D を併用することが有効である。

本論では製造業に限定しているものの、復旧曲線の簡便な評価方 法やストックを考慮できる拡張手法は、上水やガス供給システム、 建築物の給排水システム等、ストックが重要な役割を担うケースに 適用可能であり、本論で提案した手法の汎用性を高めていくことを 今後の課題としたい。また、本論では、ストックを持つことによる コストの問題、構成要素間の損傷相関の問題等については言及して いない。これらの問題についても、今後の研究課題としたい。

\section{参考文献}

1）松本俊明，中村孝明：損傷相関を考慮したストックモデルの地震時復旧 曲線, 日本地震工学会論文集第 16 巻, 第 2 号, pp. $1 \sim 11,2016.2$

2）中村孝明，境茂樹，吉川弘道：損傷相関を考慮した地震時システム性能 評価に関する研究, 日本建築学会構造系論文集, 第 76 巻, 第 661 号, pp. 713 $\sim 719,2011.3$

3) Shinozuka M, and et al. : Resilience of Integrated Power and Water Systems, Seismic Evaluation and Retrofit of Lifeline Systems, Articles from MCEER's Research Progress and Accomplishments Volumes, pp. $65-86,2004$

4) 坂本成弘：事務所ビルの地震後復旧曲線, 日本建築学会大会学術講演梗
概集，B-1 分冊，pp. 65〜 66，2007.8

5）土居賢彦，静間俊郎，中村孝明：調整池の Buffer 効果を考慮した水力発 電水路施設の復旧過程に関する研究, 土木学会論文集 $\mathrm{A} 1$ (構造・地震工学), Vol. 69, No. 3, pp. 505 515, 2013. 11

6）静間俊郎, 中村孝明, 吉川弘道 : ラダー系システムを用いた高速道路の 地震時車両通行機能性評価, 土木学会論文集 A1 (構造・地震工学), Vol.67, No. 1, pp. 86〜94, 2011. 3

7）静間俊郎, 中村孝明：復旧曲線の理論的考察と BCP への適用, 土木学会 第 1 回地震リスクマネジメントと事業継続性シンポジウム論文報告集, pp. 231 236, 2009. 11

8）星谷勝, 宮崎正敏：上水道システムの地震災害復旧の戦略と予測，土木 学会論文報告集，第 331 号, pp. 45〜 54, 1983. 3

\section{付録}

事象演算を使ったストックの効果の計算を以下に示す。(1)と(2)は ストックがあるシステムの健全事象の演算を示し、(3)と（4)はストッ クが消費される事象の演算を示している。

(1) $\mathrm{Z}_{2}$ にストックがあるケースの健全事象の演算

$$
\begin{gathered}
\left(A_{1} \cdot A_{2}+\overline{A_{1} \cdot A_{2}}\right) \cdot A_{3} \cdot A_{4} \\
=A_{3} \cdot A_{4}
\end{gathered}
$$

(2) $\mathrm{Z}_{1}$ と $\mathrm{Z}_{2}$ 双方にストックがあるケースの健全事象の演算

$$
\begin{aligned}
\left(\left(A_{1}\right.\right. & \left.\left.+\overline{A_{1}}\right) \cdot A_{2}+\overline{A_{1} \cdot A_{2}}\right) \cdot A_{3} \cdot A_{4} \\
& =\left(A_{2}+\overline{A_{1} \cdot A_{2}}\right) \cdot A_{3} \cdot A_{4} \\
& =\left(A_{2}+\overline{A_{1}}+\overline{A_{2}}\right) \cdot A_{3} \cdot A_{4} \\
& =\left(1+\overline{A_{1}}\right) \cdot A_{3} \cdot A_{4} \\
& =A_{3} \cdot A_{4}
\end{aligned}
$$

(3) $\mathrm{Z}_{2}$ にストックがあるケースのストック消費の事象演算

$$
\begin{aligned}
\left(\overline{A_{1}}\right. & \left.+\overline{A_{2}}\right) \cdot A_{3} \cdot A_{4} \\
& =\overline{A_{1} \cdot A_{2}} \cdot A_{3} \cdot A_{4}
\end{aligned}
$$

(4) $\mathrm{Z}_{1}$ と $\mathrm{Z}_{2}$ 双方にストックがあるケースのストック消費の事象演算

$$
\begin{aligned}
& \overline{A_{1}} \cdot A_{2} \cdot A_{3} \cdot A_{4}+\overline{A_{1} \cdot A_{2}} \cdot A_{3} \cdot A_{4} \\
&=\left(\overline{A_{1}} \cdot A_{2}+\overline{A_{1} \cdot A_{2}}\right) \cdot A_{3} \cdot A_{4} \\
&=\left(\overline{A_{1}} \cdot A_{2}+\overline{A_{1}}+\overline{A_{2}}\right) \cdot A_{3} \cdot A_{4} \\
&=\left(\overline{\overline{A_{1}}} \cdot\left(\overline{A_{2}}+1\right)+\overline{A_{2}}\right) \cdot A_{3} \cdot A_{4} \\
&=\left(\overline{A_{1}}+\overline{A_{2}}\right) \cdot A_{3} \cdot A_{4} \\
&=\overline{A_{1} \cdot A_{2}} \cdot A_{3} \cdot A_{4} \\
& \text { ここに、}+ \text { +は和事象、・は積事象、一は余事象である。 }
\end{aligned}
$$




\section{A STUDY ON SEISMIC RECOVERY CURVE OF MANUFACTURING FACTORY WITH STOCK}

\section{Toshiaki MATSUMOTO* and Takaaki NAKAMURA**}

* Shinozuka Research Institute, M.Eng.

** Shinozuka Research Institute, Dr.Eng.

Most of the manufacturing industries have a certain amount of stock, i.e., material, unfinished product, finished product and so on, in various location in the production process. By this reason, even in production stop due to an earthquake, it is possible to supply products to the market by consuming the stock. On the other hand, for the reason that it is economically disadvantageous to have a stock, there is a necessity for a rational measure in deciding the amount of stock to be kept. Based on above-mentioned circumstances, the authors introduced stock in a production process, and evaluated effect of improving the recovery curve by stock consumption by means of probability theory in the previous paper (Matsumoto and Nakamura 2016). However, the study of required stock amount and simultaneous consumption of multiple stock have been left as a future study.

In this paper, firstly we show the definition and evaluation method of the recovery curve and then propose a method that can be more simply evaluates recovery curve by decomposing a production process into series systems. Finally we propose a method that can consider the effect of the stock by applying stand-by redundant system Amount of required stock in addition to the simultaneous consumption and priority in the case of the multiple stock in a production process are discussed. Furthermore, applicability of the proposed method is examined by example of a production process.

Assuming a production process of a chemical plant which produces six products, amount of the stock consumption and improving effect to the recovery curve by stock were evaluated. The following results were obtained:

- Stock can be modeled as a stand-by redundant system.

- On series system, if the stock is inexhaustible, effect of stock is determined by the stock which located in the most downstream of the production process and does not depend on upstream-side-stock.

- In the evaluation of the recovery curve, effect of stock is obtained by adding the stock consumption to the amount of production without stock. And the stock consumption is obtained by subtracting the amount of production without stock from that with stock.

- If there are multiple stock in the series system, the upstream-side-stock consumption event is a subset of the downstream-side-stock consumption event.

- By consuming the upstream-side-stock preferentially, balanced (It does not concentrate consumption to a particular stock) stock consumption can be achievable.

The proposed method can be applied to the case that stock performs an important function such as water and gas supply system, water supply and drainage system of the building in addition to the manufacturing industry. Future study is to enhance the versatility of the proposed method. In addition, in this article, it does not mention the problems such as cost by having the stock and the damage correlation between components. Therefore, they are also a topic for future study. 